\title{
Geographic variation in the damselfish-red alga cultivation mutualism in the Indo-West Pacific
}

\author{
Hiroki Hata*1,3, Katsutoshi Watanabe ${ }^{1}$ and Makoto Kato ${ }^{2}$
}

\begin{abstract}
Background: On coral reefs, damselfish defend their territories from invading herbivores and maintain algal turfs, from which they harvest filamentous algae. In southern Japan, intensive weeding of indigestible algae by Stegastes nigricans results in overgrowth by one filamentous alga, Polysiphonia sp. 1. Because this alga is highly susceptible to grazing and is competitively inferior to other algae, it survives only within the protective territories of this fish species, suggesting an obligate mutualism between damselfish and their cultivated alga. The wide distribution of damselfish species through the Indo-Central Pacific raises the question of whether this species-specific mutualism is maintained throughout the geographic range of the fish. To address this question, from all 18 damselfish species we conducted comprehensive surveys of algal flora within their territories throughout the Indo-West Pacific, and identified species of Polysiphonia using morphological examination and gene sequencing data.

Results: Several species of the genus Polysiphonia were observed as a major crop in territories throughout the geographic range of S. nigricans. Polysiphonia sp. 1 occurred only in territories of S. nigricans in central areas of the IndoPacific. However, its occurrence was low from the Great Barrier Reef and Mauritius. In contrast, other indigenous Polysiphonia species, which formed a clade with Polysiphonia sp. 1, occurred in the territories of fishes from Egypt, Kenya, and the Maldives. The other Polysiphonia species in the clade only inhabited damselfish territories and were never found elsewhere.

Conclusions: Cultivation mutualism between the damselfish S. nigricans and algae of Polysiphonia was maintained throughout the Indo-West Pacific, although algal crop species and the mode of cultivation (e.g., presence/absence of selective weeding, the species composition of algal turfs) varied among localities. This finding implies that damselfish utilize indigenous Polysiphonia species in newly colonized habitats in different ways, and therefore the algal composition and means of cultivation have diverged.
\end{abstract}

\section{Background}

Mutualism is widespread in nature, even between potentially antagonistic partners. Cultivation mutualism can be defined as relationships in which the consumer promotes the growth and net survival of the species it consumes. Most species engaging in cultivation mutualism are terrestrial, and these mutualisms usually involve fungi rather than primary producers (e.g., ant-fungal mutualisms [13]). Mutualisms between primary producers and herbivores, with the exception of crops and humans, typically involve either protection of a few plants that are much larger than the herbivores (e.g., ant-Acacia mutualisms

* Correspondence: hata@sci.ehime-u.ac.jp

${ }^{1}$ Graduate School of Science, Kyoto University, Kitashirakawa-Oiwake, Sakyo, Kyoto 606-8502, Japan

Full list of author information is available at the end of the article
$[4,5])$ or facilitate pollination (e.g., fig-fig wasp mutualism $[6,7]$ ), and are thus not considered cultivation mutualism in the strict sense. Therefore, the cultivation mutualism between the territorial damselfish Stegastes nigricans and algae of Polysiphonia on coral reefs [8] is noteworthy by virtue of being marine and because it involves photosynthetic algae.

On coral reefs, damselfishes individually defend territories from invading vertebrate/invertebrate grazers and maintain algal turfs, from which they obtain all of their food $[9,10]$. These algal turfs are rich in biomass [11-14], are highly productive $[12,15]$, and are dominated by delicate, filamentous rhodophyta, especially members of the genus Polysiphonia [14,16,17]. These damselfishes browse mainly on the upright axes of filamentous algae $[18,19]$, digesting the material with a highly acidic stom- 
ach $[20,21]$, and absorbing the digested material in their long intestine with a slow gut turnover rate [22-25]. They have neither masticatory organs nor effective endogenous or exogenous carbohydrases for breaking down algal cell walls, and thus can only digest filamentous algae that have no cortical layer [19-21,26,27]. The algal turfs of the territorial damselfish, Stegastes nigricans, are a monoculture of the filamentous red alga, Polysiphonia sp. 1, in Okinawa, Japan, which is the northernmost range of this species [14]. The fish intensively defends its territory against herbivores, weeds out indigestible corticated and/ or calcareous algae, and harvests the filamentous alga. As a result, algal turfs within their small territories are dominated by only one algal species, Polysiphonia sp. 1, which is the most digestible alga species for this fish and is thus harvested by the damselfish as a staple food $[19,28]$. This Polysiphonia sp. 1 is susceptible to grazing by territorial invaders and from competition from other algae, and therefore, inhabits only the territories of this damselfish species where other herbivores are chased away and other algae are weeded out $[8,29]$. In this way, the fish and the alga are highly dependent on one another.

Reciprocal interactions between partners often vary geographically with the partners involved and the benefits received [30]. The alga-farming damselfish, S. nigricans, is widely distributed throughout the Indo-Central Pacific [31], and it is unclear whether its relationship with Polysiphonia species is maintained throughout its geographic range. This fish neither sows nor transplants the algae, and it is proposed that water-borne diaspores (carpospores and tetraspores) of the algae germinate into sporophytes/gametophytes [32,33]. However, little is known about the distribution and dispersal ability of Polysiphonia species. Damselfish larvae can potentially disperse over long distances, carried by currents during the pelagic larval stage, which lasts approximately 28 days $[34,35]$. However, genetic differentiation has been observed between populations of damselfish in the Maldives and Guam in Micronesia, suggesting that long-distance dispersal is rare [36]. The broad distribution of $S$. nigricans poses a question as to whether the cultivation mutualism occurring is also widespread. If so, is this partnership conserved throughout the geographical range of the fish? The composition of S. nigricans algal turfs have been reported from several sites covering a wide geographic distribution [14,16,37-39], however detailed and accurate classification of Polysiphonia to species level has thus far not been attempted. Morphological-based identification of filamentous red algae is highly problematic, mostly because they have a relatively simple morphology and exhibit extreme levels of phenotypic plasticity [40]. However, molecular identification using 18S rDNA sequencing is known to agree with the species taxonomy based on anatomical data in Polysiphonia algae [41]. The smallest difference between species was shown to be four bases in the 18S rDNA sequence [41], and as a result we used this criterion to distinguish species of Polysiphonia in this study. Thus, by determining the species identity of Polysiphonia algae using DNA sequencing data in concert with morphological characteristics, we explored the geographic pattern of the partnership between the fish and algal species, and detected the geographic distribution of the damselfish-algae mutualism.

\section{Results}

We surveyed 320 territories of 18 damselfish species and thoroughly examined algae from each fish territory from coral reefs in Egypt, Kenya, Mauritius, the Maldives, Thailand, Borneo, the Okinawa Islands, and the Great Barrier Reef (GBR, Table 1). A total of 21 Polysiphonia genotypes were found among 211 territories of 15 damselfish species in the Indo-West Pacific (Fig. 1). These genotypes were different from each other by more than four bases in $18 \mathrm{~S} \mathrm{rDNA}$, and therefore were treated as species. Molecular phylogenetic analyses of the collected Polysiphonia species detected four clades: A (including Polysiphonia sp. 1), B, C, and D, as shown in Fig. 1. Polysiphonia sp. 1, which had previously been found only within Stegastes nigricans territories in Okinawa, was discovered from territories of this damselfish species in Mauritius and the GBR, but nowhere else. Polysiphonia clade A species were seldom found outside territories of S. nigricans. In contrast, Polysiphonia sp. 3 of clade C occurred in the territories of 11 damselfish species and also outside damselfish territories throughout the study area. On the other hand, multiple species of Polysiphonia coexisted in the territories of S. nigricans and Hemiglyphidodon plagiometopon in some localities. In general Polysiphonia algae were rarely found outside damselfish territories. In Okinawa, two species of Polysiphonia clades $\mathrm{C}$ and $\mathrm{D}$ occurred in $9.5 \%$ and $0.6 \%$ of these extraterritorial samples, respectively, although a very closely related Neosiphonia species that lacks a prostrate axis occurred in $37.3 \%$ of the extra-territorial samples.

Fig. 2 shows the percent composition of algae in the territories of four abundant and widely-distributed damselfish species, S. nigricans, S. lividus, Plectroglyphidodon lacrymatus, and $\mathrm{H}$. plagiometopon. Algal compositions of the territories differed among fish species (two-way ANOSIM, $\mathrm{R}=0.51, \mathrm{p}=0.001$ ), and among study sites (two-way ANOSIM, $\mathrm{R}=0.51, \mathrm{p}=0.001$ ). Algal turfs of these damselfishes were dominated by filamentous rhodophyta including Polysiphonia algae. Instead of Polysiphonia, a mixture of filamentous algae of the genera Neosiphonia, Herposiphonia, Anotrichium, and Ceramium comprised substantial portions of the algal turfs in all damselfish territories from all localities except for territories of S. nigricans in Okinawa. However, Polysipho- 
Table 1: Study sites and the number of samples collected.

\begin{tabular}{|c|c|c|c|c|c|c|c|c|c|}
\hline $\begin{array}{l}\text { Study site } \\
\text { Latitude } \\
\text { Longitude }\end{array}$ & & $\begin{array}{l}\text { Egypt } \\
\text { N28 } 29^{\prime} \\
\text { E34 }\end{array}$ & $\begin{array}{c}\text { Kenya } \\
\text { S03 }^{\circ} 15^{\prime}-S 04^{\circ} 00^{\prime} \\
E 39^{\circ} 44^{\prime}-{\text { E } 40^{\circ} 08^{\prime}}^{\prime}\end{array}$ & 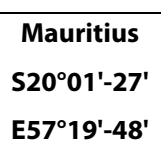 & $\begin{array}{c}\text { Maldives } \\
\mathrm{N4}^{\circ} 10^{\prime}-17^{\prime} \\
\text { E73 } 23^{\prime}-30^{\prime}\end{array}$ & $\begin{array}{c}\text { Thailand } \\
\text { N7 }{ }^{\circ} 18^{\prime}-24^{\prime} \\
\text { E99 } 12^{\circ}-17^{\prime}\end{array}$ & $\begin{array}{c}\text { Borneo } \\
\text { N5 } 58^{\prime}-\text {-N6 }^{\circ} 03^{\prime} \\
\text { E116 } \\
\end{array}$ & 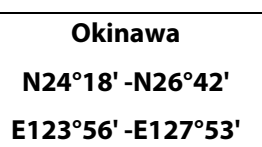 & $\begin{array}{c}\text { Great Barrier Reef } \\
S 19^{\circ} 10^{\prime} \\
E 146^{\circ} 51^{\prime}\end{array}$ \\
\hline Stegastes nigricans & (Snig) & 10 & 10 & 23 & 11 & 0 & 0 & 40 & 23 \\
\hline S. lividus & (Sliv) & - & 0 & 13 & 0 & 3 & 5 & 17 & 0 \\
\hline S. albifasciatus & (Salb) & - & 0 & - & 0 & 0 & 0 & 1 & 0 \\
\hline S. apicalis & (Sapi) & - & - & - & - & - & - & - & 8 \\
\hline S. fasciolatus & (Sfas) & - & 0 & 0 & 0 & 3 & 0 & 0 & 0 \\
\hline S. limbatus & (Slim) & - & - & 10 & - & - & - & - & - \\
\hline S. obreptus & (Sobr) & - & - & - & - & 7 & 6 & 0 & - \\
\hline S. pelicieri & (Spel) & - & - & 1 & - & - & - & - & - \\
\hline Plectroglyphidodon lacrymatus & (Plac) & 4 & 15 & 0 & 8 & 6 & 12 & 13 & 0 \\
\hline P. leucozonus & (Pleu) & 1 & 0 & 0 & 0 & 0 & 0 & 0 & 0 \\
\hline Hemiglyphidodon plagiometopon & (Hpla) & - & - & - & - & 5 & 5 & 8 & 0 \\
\hline Chrysiptera unimaculata & (Cuni) & 0 & 0 & 0 & 0 & 2 & 0 & 0 & 0 \\
\hline Dischistodus chrysopoecilus & (Dchr) & - & - & - & - & - & 6 & - & - \\
\hline D. perspicillatus & (Dper) & - & - & - & - & 6 & 2 & - & 0 \\
\hline D. prosopotaenia & (Dpro) & - & - & - & - & 0 & 0 & 19 & 0 \\
\hline Neoglyphidodon nigroris & (Nnig) & - & - & - & - & 2 & 0 & 0 & 0 \\
\hline Pomacentrus aquilus & (Paqu) & 0 & 8 & 0 & - & - & - & - & - \\
\hline P. tripunctatus & (Ptri) & - & - & - & - & 4 & 3 & - & 0 \\
\hline Outside territory & (Out) & 0 & 0 & 0 & 0 & 0 & 0 & 158 & 0 \\
\hline
\end{tabular}

- denotes the absence of the fish species at the site. Abbreviations of species in parentheses were used in Fig. 1. 


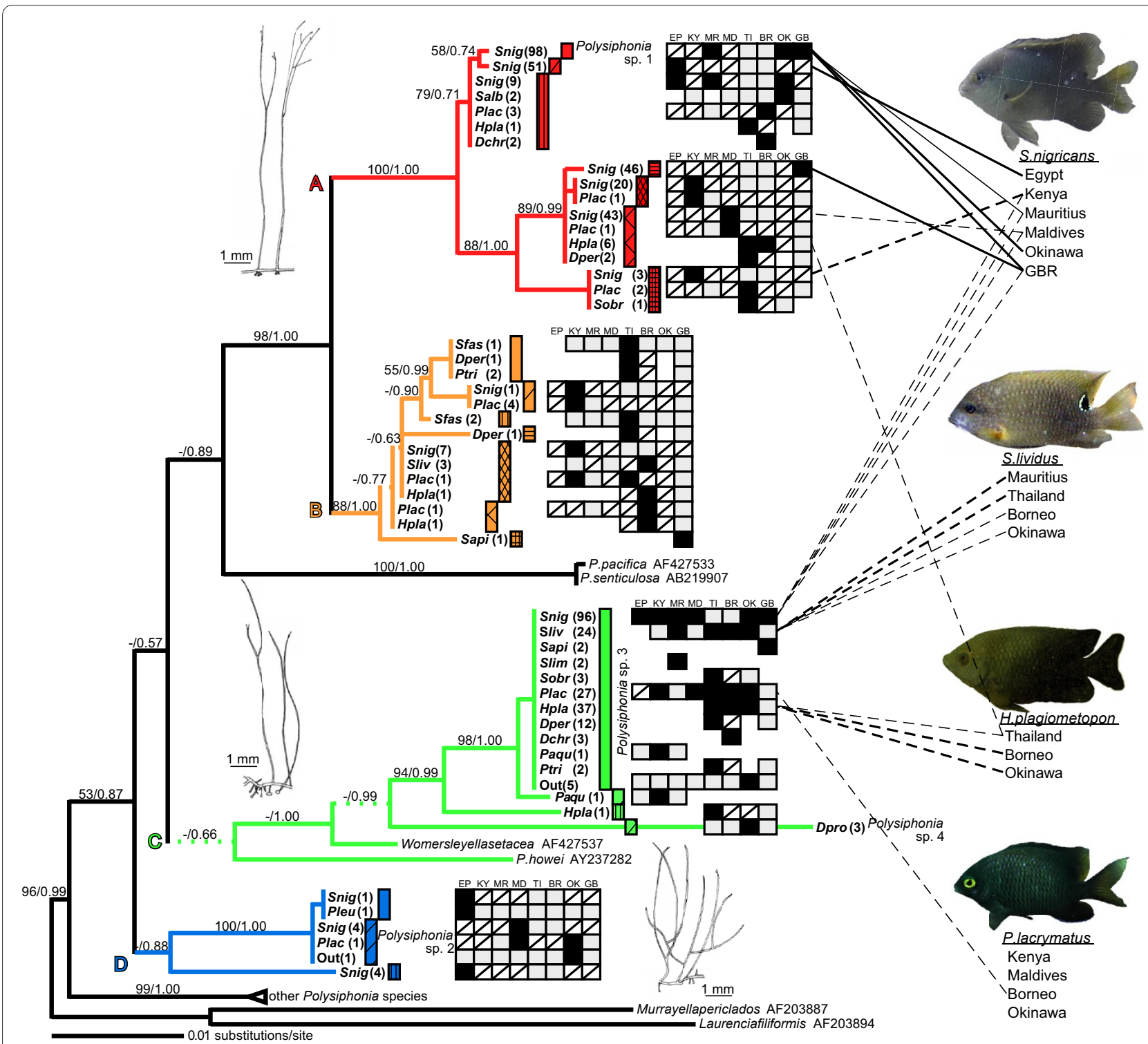

Figure 1 Phylogeny of Polysiphonia algae found inside and outside the territories of $\mathbf{1 5}$ damselfish species. Each alga is denoted by the abbreviation of its damselfish host species that is shown in Table 1. 'Out' indicates algae collected outside damselfish territories. Numbers in parentheses indicate the number of DNA samples including partially sequenced samples. Data presented as the scientific names of algae with accession numbers denote citations from the NCBI GenBank. Black blocks indicate the locations from which the algae were collected (EP, Egypt; KY, Kenya; MR, Mauritius; MD, the Maldives; TI, Thailand; BR, Borneo; OK, Okinawa; GB, the GBR). Gray blocks indicate areas inhabited by damselfish for which we have no data; blocks with slashes denote sites inhabited by damselfish where the alga was not found; open blocks indicate areas uninhabited by the fish. The tree was obtained using the ML method based on 1531 bp of $18 \mathrm{~S}$ rDNA. Branches that collapse in MP, ML, and/or BI trees are presented as broken lines. Nodal support was assessed by the bootstrap value of MP and posterior probabilities of BI (above branches, MP/BI, respectively). Four abundant and widely-distributed damselfish species are listed on the right column, and their localities were linked with inhabitant Polysiphonia algae. Broad and narrow links indicate that the alga occurred in $\geq 50 \%$ or $\geq 25 \%$ of the territories of the damselfish species at these sites, respectively. Solid and broken lines indicate that the algal species occurred only within the territories of the fish species or that they also occurred in territories of other fish species and/or outside the damselfish territories, respectively.

nia species in clade A, to which Polysiphonia sp. 1 belongs, were consistently the staple species in S. nigricans territories at all study sites, although occupancy varied among study sites. Occupancy was higher in Okinawa than at the other sites (Tukey-Kramer test, Okinawa vs. all other sites, all $\mathrm{p}<0.05$ ). Polysiphonia sp. 1 (plain red bar in Figs. 1, 2) dominated S. nigricans territories in Okinawa, and also occurred in territories in Mauritius and the GBR. However, coverage of Polysiphonia sp. 1 in territories of S. nigricans were significantly higher from Okinawa than from Mauritius or the GBR (Fig. 3; TukeyKramer test, both pairs, $\mathrm{p}<0.05)$. In Okinawa, S. nigri- 
(a) Stegastes nigricans

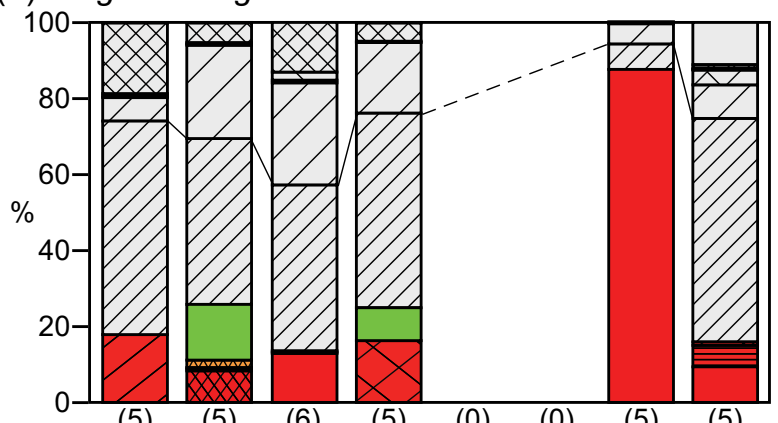

(b) S. lividus

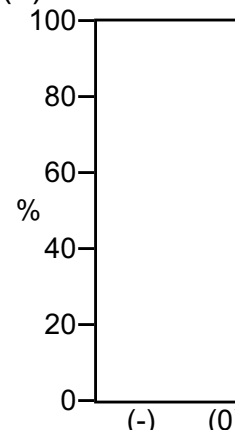

$(-) \quad(0)$

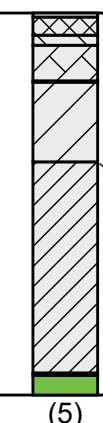

(5)
(5)

(0) (0)

(5)

(5)

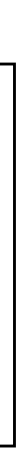

(3) (5)

\begin{tabular}{|l|}
\hline$\square$ Cyanophyta \\
$\square$ Heterokontophyta \\
$\square$ Calcareous chlorophyta \\
$\square$ Filamentous chlorophyta \\
$\square$ Calcareous rhodophyta \\
$\square$ Corticated rhodophyta \\
$\square$ Other filamentous \\
rhodophyta \\
$\square$ Polysiphonia clade D \\
$\square$ Polysiphonia clade C \\
$\square$ Polysiphonia clade B \\
$\square$ Polysiphonia clade A \\
\hline
\end{tabular}

(c) P. lacrymatus

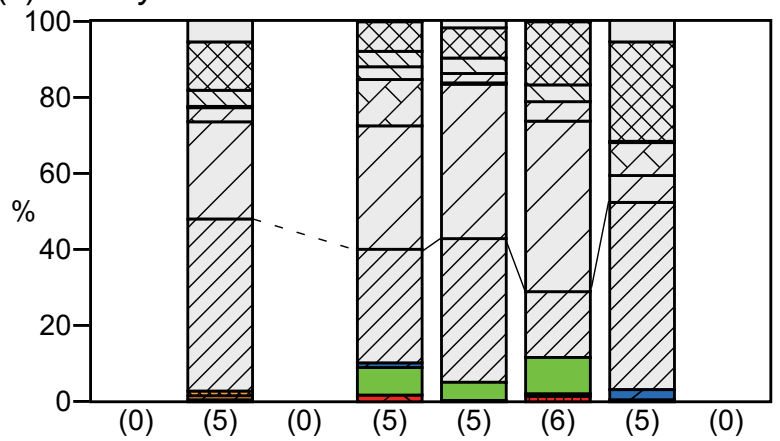

(d) H. plagiometopon

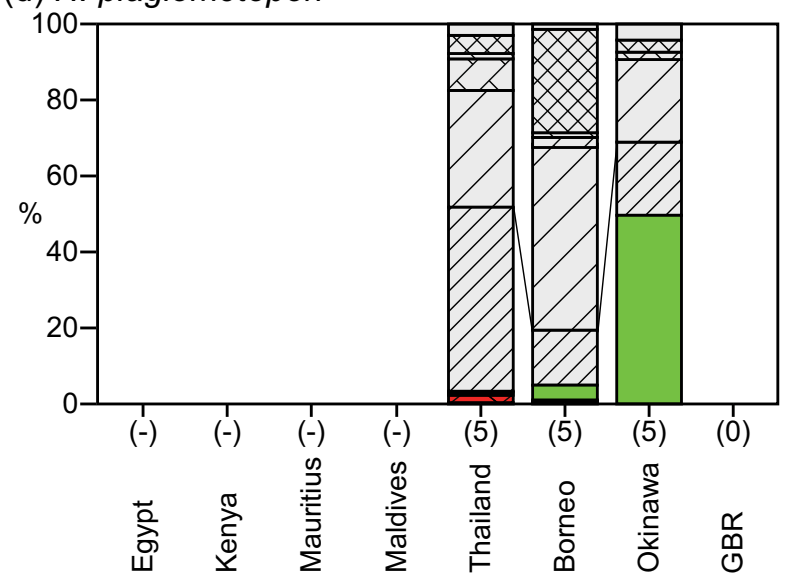

Figure 2 Percent composition of algal turfs of four damselfish species in the Indo-West Pacific. (a) Stegastes nigricans, (b) S. lividus, (c) Plectroglyphidodon lacrymatus, and (d) Hemiglyphidodon plagiometopon. Colors and patterns of areas correspond to clades and species of Polysiphonia shown in Fig. 1, i.e., red, yellow, green, and blue indicate clades A, B, C, and D, respectively. Grey areas indicate composition of other algae. The numeral or hyphen (-) under each column indicates the number of samples or the absence of the fish species, respectively. 


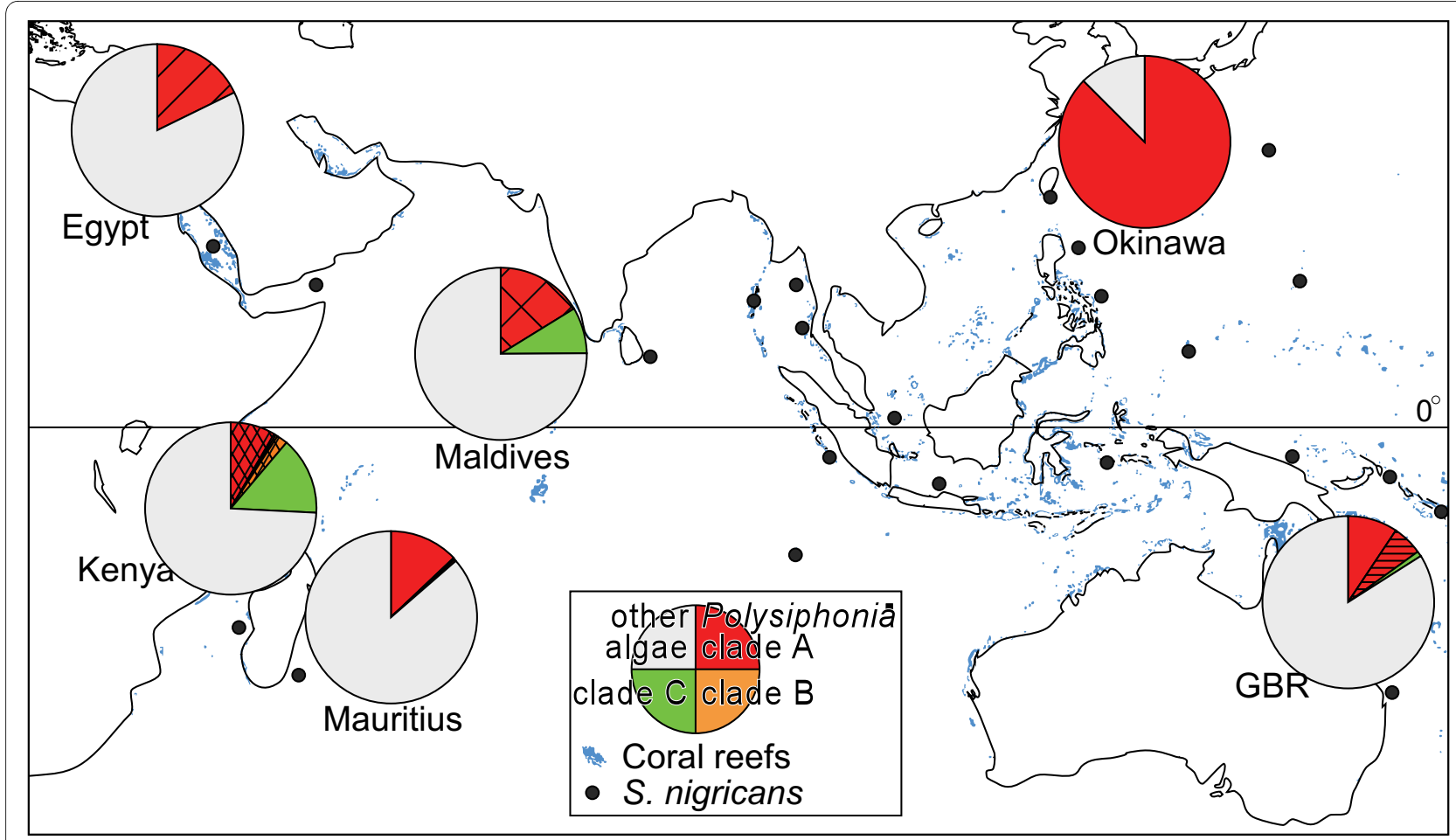

Figure 3 Geographic mosaic of partnerships between Stegastes nigricans and Polysiphonia algae in the Indo-West Pacific. The circle graphs indicate the biomass composition of algal species in territories of S. nigricans at our study sites. Colors and patterns correspond to the clades and species of Polysiphonia shown in Fig. 1, and grey indicates the presence of algae other than Polysiphonia spp. Light blue dots and black closed circles indicate the areas of coral reefs and S. nigricans, respectively.

cans depended exclusively on this algal species, forming monocultures, whereas in Mauritius and the GBR, Polysiphonia sp. 1 did not always occur in the territories of $\mathrm{S}$. nigricans and did not dominate where it did occur.

From Egypt, Kenya, the Maldives, and the GBR, other species of clade A occurred in the algal turfs of S. nigricans. The Polysiphonia species that was dominant in territories of S. nigricans from Egypt was a sister branch of Polysiphonia sp. 1 (Fig. 1). However, the dominant Polysiphonia species from Kenya and the Maldives were not closely related to Polysiphonia sp. 1, and they also inhabited the territories of other damselfish species. Other damselfishes, i.e., Stegastes lividus, Plectroglyphidodon lacrymatus, and $H$. plagiometopon, shared Polysiphonia sp. 3 (plain green bar in Figs. 1, 2) in most localities.

\section{Discussion}

\section{Mutualism and other relationships between territorial} damselfishes and algae in the Indo-West Pacific

Throughout its geographical range, the territorial damselfish Stegastes nigricans maintained algal turfs that were consistently inhabited by local Polysiphonia species belonging to a single phylogenetic clade (clade A). Polysiphonia sp. 1 of clade A was common in the territories of S. nigricans from the central Indo-West Pacific, but not from Egypt, Kenya, or the Maldives, where other indigenous Polysiphonia species of clade A were utilized instead of Polysiphonia sp. 1 (Fig. 3). Two species of Polysiphonia that occurred in the territories of S. nigricans from Egypt and the GBR, and Polysiphonia sp. 1, were found only in S. nigricans territories. Additionally, two other Polysiphonia species were abundant and almost exclusively inhabited S. nigricans territories from the Maldives and Kenya. These results suggest that $S$. nigricans provides these Polysiphonia species with their sole or primary habitat, and harvests these filamentous algae as a staple food in all localities from the Indo-West Pacific. In this way, the mutualism between S. nigricans and its crop Polysiphonia species was maintained, but the partner Polysiphonia species varied among localities. Phylogenetic results suggest that shifts in crop algal species within clade A have occurred at least a few times in the West-Central Indian Ocean. Furthermore, the occurrence of Polysiphonia species in clade A in the territories of S. nigricans varied geographically, being highest in Okinawa, where the damselfish weed out algae other than the crop algal species. From Okinawa, where the relationship between the damselfish and Polysiphonia alga attains obligate mutualism, a single species of Polysiphonia dominated the territories of S. nigricans to form nearly pure monocultures, 
whereas other Polysiphonia species rarely coexisted within the territories. In the case of fungus-farming ants and termites, each colony is maintained as a monoculture of a genetically single cultivar $[42,43]$, and this is thought to be a key stabilizing factor in the mutualistic interaction on an evolutionary time scale [44]. In the GBR and Mauritius, the coverage of Polysiphonia sp. 1 in territories was lower than in Japan, suggesting that the fish utilized not only this alga but also other algal species, as well as other resources such as detritus trapped in the algal turf $[16,37]$.

Conversely, from most locations the algal turfs of three other species of damselfishes, S. lividus, P. lacrymatus, and $H$. plagiometopon, were dominated by filamentous rhodophyta, and shared a generalist Polysiphonia species. This discrepancy in the structure of algal turfs between $S$. nigricans and other damselfish species is caused by differences in the inherent farming strategies of fishes, that is, intensive farming and extensive farming. In the intensive farming method, damselfish defend their small monoculture patch by selective weeding and vigorous exclusion of invaders. In contrast, in extensive farming, damselfish defend large but mixed-species algal turfs only by excluding invaders $[16,17,28,45]$.

The algal turfs of most damselfishes are known to be dominated by filamentous rhodophyta, but the dominant algal genera shift within the subclass Rhodymeniophycidae with geographic range as well as on much smaller scales such as reef zones on a coral reef $[10,17]$, and species-specificity has been known only between a damselfish, S. nigricans, and Polysiphonia sp. 1 in Okinawa [8]. Extensive molecular phylogenetic analyses of algae enabled us to detect patterns between damselfish and Polysiphonia species at a species level, as this method is effective in detecting species interactions and coevolutionary processes in other mutualistic systems [46,47]. More intensive research on algal turfs of damselfishes at each location, and species identifications of Polysiphonia algae using DNA sequences are needed to understand the partnerships between damselfish and Polysiphonia algae, their degrees of specialization in this cultivation mutualism system, and their geographic variations. Other than our study sites and focus species, Polysiphonia species are known to be abundant in the territories of damselfishes all around the Pacific, including those of S. apicalis in the Gulf of Thailand [48], S. lividus in Guam [49], S. nigricans, Neoglyphidodon nigroris, Plectroglyphidodon lacrymatus, and $P$. dickii in Papua New Guinea [16,17], Pomacentrus adelus, $P$. tripunctatus, and $P$. wardi in the GBR [17], S. nigricans in Fiji [50], S. fasciolatus in Tonga [49], and Microspathodon dorsalis in the Gulf of California [51], and even in the Atlantic ( $S$. planifrons in Jamaica) [52]. Studies of these species and locations would improve our understanding of mutualism between herbivorous fish and red algae on coral reefs.

\section{Geographic structure of the damselfish-red alga mutualism systems}

The mutualism between a marine herbivorous fish, S. nigricans, and the filamentous rhodophyte Polysiphonia showed an asymmetric species-specific pattern in which indigenous Polysiphonia species exclusively inhabited the territories of $S$. nigricans, but not necessarily dominated the territories except in Okinawa. This mosaic pattern in the cultivation system is thought to be caused by differences in the history of interaction and coevolution between the fish and the algae and in the community of interacting organisms at each coral reef. Selective weeding by $S$. nigricans is a fundamental trait mediating this mutualism, and this maintains a near monoculture of Polysiphonia sp. 1 in Okinawa [8]. Weeding behavior by S. nigricans has been observed 0.5 times per 10 minutes in Okinawa [19], and 0.7 times per 10 minutes in Kenya $(\mathrm{n}=3$ individuals, 1 observation each, our primary observation). In Kenya, however, three species of Polysiphonia coexisted with each other and with other algae in the territories. On the other hand, weeding behavior was not observed from the Maldives at least in our observation (n $=5$ individuals, 1 observation each, our primary observation) where territories of $S$. nigricans were inhabited by two species of Polysiphonia. Further study on the variation in weeding behavior, its efficiency in local conditions, and its genetic basis are needed to explain this discrepancy among localities. With respect to local environments, sea urchins were more abundant inside territories of S. nigricans in Okinawa than in Kenya and the Maldives, and in Okinawa invading herbivores were also much more abundant than in Kenya (Additional file 1: Fig. S1). Additionally, twelve species of territorial damselfishes coexist on reefs in Okinawa (Table 1). Therefore, the density, diversity, and composition of competitors may drive the selection mosaic [30]. Further studies on population genetics of damselfishes and Polysiphonia algae, and measurement of fitness under interactions in each locality in this geographic range will reveal how geographic variation is structured and whether the geographic mosaic theory of coevolution is valid [53].

Geographic variation in the partnership and specialization between the cultivation mutualism participants has also been reported between a fungus-growing termite and its crop fungus [54,55]. In this system, Microtermes termites are generalists and utilize genetically diverse symbiont fungi in South Africa, whereas the Microtermes species in western Africa (Senegal and Cameroon) are specialists and are associated with a single narrow lineage of fungi. The geographic patterns of mutualism are not 
obvious in fungus-growing attine ants or ambrosia beetles [56], but may be generally structured as observed from plant cultivation systems in humans [57].

\section{Conclusions}

This study revealed that the intensive-farming damselfish Stegastes nigricans maintains similar algal turfs dominated or subdominated by a clade of Polysiphonia species throughout a wide geographic range, but that the crop alga species varies among distantly isolated localities. These Polysiphonia species inhabited territories of fish species exclusively or nearly exclusively. Therefore, cultivation mutualism between S. nigricans and Polysiphonia algae was maintained throughout the geographic range of $S$. nigricans, with some algal shifts in crops occurring from the West Indian Ocean and the Red Sea. This damselfish-alga mutualism is a model system through which we can approach the origin, establishment, and coevolutionary processes of the cultivation system.

\section{Methods \\ Sampling}

We collected Polysiphonia spp. and other algal species from the territories of 18 damselfish species from coral reefs at eight sites in the Indo-West Pacific from 2003 to 2006: Egypt (the Red Sea), Kenya, Mauritius, the Maldives, southern Thailand (the Andaman Sea), Sabah in Borneo, the Okinawan Islands in southern Japan, and the GBR in Australia (Table 1). Each algal sample was collected from each territory of damselfishes. We defined damselfish territory as the place where the territory holder fed on algae and defended against conspecific and heterospecific herbivores [58]. Whether a site was located within or outside of a damselfish territory was determined by $20 \mathrm{~min}$ of observation immediately prior to sampling. To facilitate thorough sampling of algae from outside the territories of fishes in Okinawa, Japan, we set line transects from the beach to offshore areas, perpendicular to the shoreline, at 2, 4, and 10 reef flats around

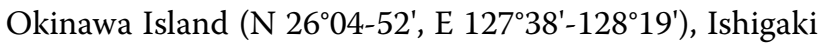
Island (N 24 $\left.19-36^{\prime}, \mathrm{E} 124^{\circ} 04-20^{\prime}\right)$, and Iriomote Island (N $24^{\circ} 15-25^{\prime}$, E $123^{\circ} 40-55^{\prime}$ ) [6]. We set $1 \times 1 \mathrm{~m}$ quadrats outside the territories at 50-m intervals along each transect and used a knife to scrape all of the algae and seagrass within the quadrats into mesh bags. In total, 158 samples were collected from outside damselfish territories.

Algal samples were immediately preserved in $100 \%$ ethanol. In the laboratory, samples were rinsed with distilled water, and all Polysiphonia algae were sorted under a microscope. Polysiphonia algae, including the small thalli of the algae, were classified into species using molecular data (see below). The percent composition of Polysiphonia species in algal turfs was quantified by spreading the algal samples evenly in a Petri dish marked with a grid, identifying the algae on fixed 100 crossing points using molecular data when necessary, and counting the occurrence of each algal species.

\section{Molecular methods}

We extracted total DNA from field-collected, ethanolpreserved algae using Ampdirect ${ }^{\circ}$ Plus (Shimadzu, Japan). A fragment of the $18 \mathrm{~S}$ ribosomal RNA gene was amplified by polymerase chain reaction (PCR) using the primers $5^{\prime}$ ACCTGGTTGATCCTGCCAG-3' and G07, and was directly sequenced using these two primers and four additional primers [59]. Polysiphonia species can be classified at the species level using $18 \mathrm{~S}$ rDNA sequences [41]. All sequences were deposited in the DDBJ database [accession nos. AB505058-74].

\section{Phylogenetic analyses}

Maximum parsimony (MP) and maximum likelihood (ML) analyses were conducted using PAUP* 4.0b10 [60], and Bayesian inference (BI) was conducted using MrBayes 3.2 [61]. MP analyses employed the heuristic search option with TBR branch-swapping and 1000 random-taxon-addition replicates, identifying the 40 most parsimonious trees of length $=447$, C.I. $=0.593$, and R.I. $=0.770$. Heuristic MP bootstrap analysis consisted of 1000 pseudoreplicates with 10 random-taxon-addition replicates per pseudoreplicate. The likelihood ratio test implemented in ModelTest 3.06 [62] found the $\operatorname{TrN}+\mathrm{I}+$ $\mathrm{G}$ model best fitting the sequence data, and this model was employed in a heuristic ML analysis. A heuristic search with 10 random-taxon-addition sequences and TBR branch swapping was performed. BI was performed based on the model HKY + I + G, which was selected by MrModeltest 2.3 [63], with 2,000,000 generations, sampling every 100 generations. The first 500 trees were discarded as burn-in after confirming chain stationarity from plots of likelihood against generation. The average standard deviation of split frequencies after 2,000,000 generations was 0.0033 .

\section{Statistical analyses}

Algal composition of damselfish territories were analyzed using two-way ANOSIM [64] with fish species and study site as factors. The percent composition of Polysiphonia species and that of Polysiphonia clades in the territories of Stegastes nigricans were compared among locations using a Tukey-Kramer test. ANOSIM was conducted using PRIMER 6 (Plymouth Marine Laboratories, UK). 


\section{Additional material}

Additional file 1 Geographic variation in densities of herbivorous fishes and sea urchins inside territories of Stegastes nigricans. (a) frequencies in which Stegastes nigricans chased invading fishes out of their territories per 10 minutes, (b) the densities of sea urchins found inside the territories of S. nigricans in the three localities of Kenya, the Maldives, and Okinawa. Numbers in parentheses indicate the number of individual damselfish we observed. Different letters indicate significant differences at the $5 \%$ level by the Games-Howell test. *Observation data in Okinawa are cited from [28].

\section{Authors' contributions}

$\mathrm{HH}$ carried out the design of the study, field surveys, the molecular phylogenetic study, data analyses, and manuscript composition. KW carried out molecular phylogenetic study and manuscript composition. MK participated in the design of the study and carried out manuscript composition. All authors read and approved the final manuscript.

\section{Acknowledgements}

We thank N. Knowlton, W. M. Todd and two anonymous reviewers for critical review of the manuscript; S. Yasumura, WWF Japan, J. Toyoshima, the International Coral Reef Research and Monitoring Center, R. M. Pillay, C. Samyan, Mauritius Oceanography Institute, D. Kirugara, B. Orembo, Kenya Marine and Fisheries Research Institute, K. Ikejima, Asian Institute of Technology, S. Senoo, Borneo Marine Research Institute, A. Iguchi, James Cook University, for field studies; M. Hori, T. Sota for laboratory studies. This work was supported by Research Fellowships of the Japanese Society for the Promotion of Science for Young Scientists, and the Global COE Program A06 of the Ministry of Education, Culture, Sports, Science and Technology, Japan.

\section{Author Details}

${ }^{1}$ Graduate School of Science, Kyoto University, Kitashirakawa-Oiwake, Sakyo, Kyoto 606-8502, Japan, ${ }^{2}$ Graduate School of Human and Environmental Studies, Kyoto University, Yoshida-Nihonmatsu, Sakyo, Kyoto 606-8501, Japan and ${ }^{3}$ Graduate School of Science and Engineering, Ehime University, 2-5 Bunkyo, Matsuyama, Ehime 790-8577, Japan

Received: 4 February 2010 Accepted: 18 June 2010

Published: 18 June 2010

\section{References}

1. Mueller UG, Gerardo NM, Aanen DK, Six DL, Schultz TR: The evolution of agriculture in insects. Annu Rev Ecol Evol Syst 2005, 36:563-595.

2. Schultz TR, Mueller UG, Currie CR, Rehner SA: Reciprocal illumination: a comparison of agriculture in Humans and in fungus-growing ants. In Insect-fungal associations: ecology and evolution Edited by: Vega FE, Blackwell M. New York: Oxford University Press; 2005:149-190.

3. Schultz TR, Brady SG: Major evolutionary transitions in ant agriculture. Proc Natl Acad Sci USA 2008, 105:5435-5440.

4. Heil M, McKey D: Protective ant-plant interactions as model systems in ecological and evolutionary research. Annu Rev Ecol Evol Syst 2003, 34:425-453

5. Palmer TM, Brody AK: Mutualism as reciprocal exploitation: African plant-ants defend foliar but not reproductive structures. Ecology 2007, 88:3004-3011.

6. Weiblen GD: How to be a fig wasp. Annu Rev Entomol 2002, 47:299-330.

7. Herre EA, Jandér KC, Machado CA: Evolutionary ecology of figs and their associates: recent progress and outstanding puzzles. Annu Rev Ecol Evol Syst 2008, 39:439-458

8. Hata H, Kato M: A novel obligate cultivation mutualism between damselfish and Polysiphonia algae. Biol Lett 2006, 2:593-596.

9. Branch GM, Harris JM, Parkins C, Bustamante RH, Eekhout S: Algal 'gardening' by grazers: a comparison of the ecological effects of territorial fish and limpets. In Plant-animal interactions in the marine benthos Edited by: John DM, Hawkins SJ, Price JH. Oxford: Clarendon Press; 1992:405-423

10. Ceccarelli DM, Jones GP, MCCook LJ: Territorial damselfishes as determinants of the structure of benthic communities on coral reefs. Oceanogr Mar Biol Annu Rev 2001, 39:355-389.
11. Sammarco PW: Effects of fish grazing and damselfish territoriality on coral reef algae. I. Algal community structure. Mar Ecol Prog Ser 1983, $13: 1-14$

12. Klumpp DW, McKinnon D, Daniel P: Damselfish territories: zones of high productivity on coral reefs. Mar Ecol Prog Ser 1987, 40:41-51.

13. Ferreira CEL, Gonçalves JEA, Coutinho R, Peret AC: Herbivory by the dusky damselfish Stegastes fuscus (Cuvier, 1830) in a tropical rocky shore: effects on the benthic community. J Exp Mar Biol Ecol 1998, 229:241-264.

14. Hata H, Nishihira M, Kamura S: Effects of habitat-conditioning by the damselfish Stegastes nigricans on community structure of benthic algae. J Exp Mar Biol Ecol 2002, 280:95-116.

15. Russ GR: Is rate of removal of algae by grazers reduced inside territories of tropical damselfishes? J Exp Mar Biol Ecol 1987, 110:1-17.

16. Jones GP, Santana L, McCook LJ, McCormick MI: Resource use and impact of three herbivorous damselfishes on coral reef communities. Mar Ecol Prog Ser 2006, 328:215-224.

17. Ceccarelli DM: Modification of benthic communities by territorial damselfish: a multi-species comparison. Coral Reefs 2007, 26:853-866.

18. Hiatt RW, Strasburg DW: Ecological relationships of the fish fauna on coral reefs of the Marshall Islands. Ecol Monogr 1960, 30:65-127.

19. Hata H, Kato M: Weeding by the herbivorous damselfish Stegastes nigricans in nearly monocultural algae farms. Mar Ecol Prog Ser 2002, 237:227-231.

20. Zemke-White WL, Clements KD, Harris PJ: Acid lysis of macroalgae by marine herbivorous fishes: myth or digestive mechanism? J Exp Ma Biol Ecol 1999, 233:95-113.

21. Zemke-White WL, Clements KD, Harris PJ: Acid lysis of macroalgae by marine herbivorous fishes: effects of acid $\mathrm{pH}$ on cell wall porosity. J Exp Mar Biol Ecol 2000, 245:57-68.

22. Lassuy DR: Diet, intestinal morphology, and nitrogen assimilation efficiency in the damselfish, Stegastes lividus, in Guam. Environ Biol Fish 1984, 10:183-193.

23. Horn MH: Biology of marine herbivorous fishes. Oceanogr Mar Biol Annu Rev 1989, 27:167-272

24. Polunin NVC, Harmelin-Vivien M, Galzin R: Contrasts in algal food processing among five herbivorous coral-reef fishes. J Fish Biol 1995, 47:455-465

25. Cleveland A, Montgomery WL: Gut characteristics and assimilation efficiencies in two species of herbivorous damselfishes (Pomacentridae: Stegastes dorsopunicans and S. planifrons). Mar Biol 2003, 142:35-44

26. Lobel PS: Trophic biology of herbivorous reef fishes: alimentary $\mathrm{pH}$ and digestive capabilities. J Fish Biol 1981, 19:365-397.

27. Skea GL, Mountfort DO, Clements KD: Contrasting digestive strategies in four New Zealand herbivorous fishes as reflected by carbohydrase activity profiles. Comp Biochem Phys A 2007, 146:63-70.

28. Hata H, Kato M: Monoculture and mixed-species algal farms on a coral reef are maintained through intensive and extensive management by damselfishes. J Exp Mar Biol Ecol 2004, 313:285-296.

29. Hata H, Kato M: Demise of monocultural algal farms by exclusion of territorial damselfish. Mar Ecol Prog Ser 2003, 263:159-167.

30. Thompson JN: The geographic mosaic of coevolution Chicago: The University of Chicago Press; 2005

31. Allen GR, Emery AR: A review of the pomacentrid fishes of the genus Stegastes from the Indo-Pacific, with descriptions of two new species. Indo-Pacific Fishes 1985, 3:1-31.

32. Lee WJ, Lee IK: Mixed phases reproduction of Polysiphonia morrowi Harvey (Rhodomelaceae, Rhodophyta) in culture. JPN J Phycol 1991 39:115-121.

33. Yao J, Li D, Yu S, Liu J, Duan D: Formation and early development of tetraspores of Polysiphonia urceolata (Rhodomelaceae, Rhodophyta). Chinese J Ocean Limnol 2009, 27:365-369.

34. Thresher RE, Colin PL, Bell LJ: Planktonic duration, distribution and population structure of Western and Central Pacific damselfishes (Pomacentridae). Copeia 1989, 1989:420-434.

35. Wellington GM, Victor BC: Planktonic larval duration of one hundred species of Pacific and Atlantic damselfishes (Pomacentridae). Mar Biol 1989, 101:557-567.

36. Lacson JM, Clark S: Genetic divergence of Maldivian and Micronesian demes of the damselfish Stegastes nigricans, Chrysiptera biocellata, C. glauca, C. leucopoma (Pomacentridae). Mar Biol 1995, 121:585-590. 
37. Wilson S, Bellwood DR: Cryptic dietary components of territorial damselfishes (Pomacentridae, Labroidei). Mar Ecol Prog Ser 1997, 153:299-310.

38. Lison de Loma T, Ballesteros E: Microspatial variability inside epilithic algal communities within territories of the damselfish Stegastes nigricans at La Réunion (Indian Ocean). Bot Mar 2002, 45:316-323.

39. Zemke-White LW, Beatson EL: Algal community composition within territories of the damselfish Stegastes nigricans (Pomacentridae, Labroidei) in Fiji and the Cook Islands. South Pacific Journal of Natural Science 2005, 23:43-47.

40. Saunders GW: Applying DNA barcoding to red macroalgae: a preliminary appraisal holds promise for future applications. Phil Trans $R$ Soc B 2005, 360:1879-1888.

41. Choi HG, Kim MS, Guiry MD, Saunders GW: Phylogenetic relationships of Polysiphonia (Rhodomelaceae, Rhodophyta) and its relatives based on anatomical and nuclear small-subunit rDNA sequence data. Can J Bot 2001, 79:1465-1476.

42. Paulsen $\mathrm{M}$, Boomsma Jj: Mutualistic fungi control crop diversity in fungus-growing ants. Science 2005, 307:741-744.

43. Aanen DK, de Fine Licht HH, Debets AJM, Kerstes NAG, Hoekstra RF, Boomsma JJ: High symbionts relatedness stabilizes mutualistic cooperation in fungus-growing termites. Science 2009, 326:1103-1106.

44. FrankSA: Host-symbiont conflict over the mixing of symbiotic lineages. Proc R Soc Lond B 1996, 263:339-344.

45. Hoey AS, Bellwood DR: Damselfish territories as a refuge for macroalgae on coral reefs. Coral Reefs 2010, 29:107-118.

46. Herre EA, Knowlton N, Mueller UG, Rehner SA: The evolution of mutualism: exploring the paths between conflict and cooperation. Trends Ecol Evol 1999, 14:49-53.

47. Ollerton J: "Biological Barter": patterns of specialization compared across different mutualisms. In Plant-pollinator interactions: from specialization to generalization Edited by: Waser NM, Ollerton J. Chicago: University of Chicago Press; 2006:411-435.

48. Kamura S, Choonhabandit S: Algal Communities within territories of the damselfish Stegastes apicalis and the effects of grazing by the seaurchin Diadema spp. in the Gulf of Thailand. Galaxea 1986, 5:175-194.

49. Lassuy DR: Effects of "farming" behavior by Eupomacentrus lividus and Hemiglyphidodon plagiometopon on algal community structure. Bull Mar Sci 1980, 30:304-312.

50. Gobler CJ, Thibault DB, Davis TW, Curran PB, Peterson BJ, Liddle LB: Algal assemblages associated with Stegastes sp. territories on Indo-Pacific coral reefs: characterization of diversity and controls on growth. J Exp Mar Biol Ecol 2006, 336:135-145.

51. Montgomery WL: The impact of non-selective grazing by the giant blue damselfish, Microspathodon dorsalis, on algal communities in the Gulf of California, Mexico. Bull Mar Sci 1980, 30:290-303.

52. Brawley SH, Adey WH: Territorial behavior of threespot damselfish Eupomacentrus planifrons increases reef algal biomass and productivity. Environ Biol Fish 1977, 2:45-51.

53. Gomulkiewicz R, Drown DM, Dybdahl MF, Godsoe W, Nuismer SL, Pepin KM, Ridenhour BJ, Smith Cl, Yoder JB: Dos and don'ts of testing the geographic mosaic theory of coevolution. Heredity 2007, 98:249-258.

54. Aanen DK, Eggleton P, Rouland-Lefèvre C, Guldberg-Frøslev T, Rosendahl $\mathrm{S}$, Boomsma JJ: The evolution of fungus-growing termites and their mutualistic fungal symbionts. Proc Natl Acad Sci USA 2002, 99:14887-14892.

55. Aanen DK, Ros VID, de Fine Licht HH, Mitchell J, de Beer ZW, Slippers B, Rouland-Lefèvre C, Boomsma JJ: Patterns of interaction specificity of fungus-growing termites and Termitomyces symbionts in South Africa. BMC Evol Biol 2007, 7:115.

56. Caldera EJ, Poulsen M, Suen G, Currie CR: Insect symbioses: a case study of past, present, and future fungus-growing ant research. Environ Entomol 2009, 38:78-92.

57. Diamond J: Evolution, consequences and future of plant and animal domestication. Nature 2002, 418:700-707.

58. Kohda $\mathrm{M}$ : Intra- and interspecific territoriality of a temperate damselfish Eupomacentrus altus, (Teleostei: Pomacentridae). Physiol Ecol Japan 1984, 21:35-52.

59. Saunders GW, Kraft GT: Small-subunit rRNA gene sequences from representatives of selected families of the Gigartinales and Rhodymeniales (Rhodophyta). 1. evidence for the Plocamiales ord.nov. Can J Bot 1994, 72:1250-1263.
60. Swofford DL: Paup*, phylogenetic analysis using parsimony (*and other methods). Version 4. Sunderland, Massachusetts, Sinauer Associates; 2002

61. Huelsenbeck JP, Ponquist F: MRBAYES: Bayesian inference of phylogenetic trees. Bioinformatics 2001, 17:754-755.

62. Posada D, Crandall KA: MODELTEST: testing the model of DNA substitution. Bioinformatics 1998, 14:817-818.

63. Nylander JAA: MrModeltest v2. Uppsala University; 2004. Program distributed by the author. Evolutionary Biology Centre

64. Clarke KR, Warwick RM: Similarity-based testing for community pattern: the two-way layout with no replication. Mar Biol 1994, 118:167-176.

doi: 10.1186/1471-2148-10-185

Cite this article as: Hata et al., Geographic variation in the damselfish-red alga cultivation mutualism in the Indo-West Pacific BMC Evolutionary Biology 2010, 10:185

\section{Submit your next manuscript to BioMed Central and take full advantage of:}

- Convenient online submission

- Thorough peer review

- No space constraints or color figure charges

- Immediate publication on acceptance

- Inclusion in PubMed, CAS, Scopus and Google Scholar

- Research which is freely available for redistribution
C Biomed Central 